\title{
DESDOBRAMENTOS DA REGULAÇÃO DA INTERNET: MODELOS TEÓRICOS E ATORES ENVOLVIDOS
}

\author{
Amanda Nunes Lopes Espiñeira Lemosi \\ Ana Cláudia Farranhaii \\ Isaac Reisiii
}

\section{RESUMO}

Esse trabalho mapeia os atores envolvidos na regulação da Internet brasileira a partir das audiências públicas realizadas no Congresso Nacional, à época da elaboração do Marco Civil da Internet e no Supremo Tribunal Federal no âmbito das ações que questionam a constitucionalidade de dispositivos desse marco regulatório (ADI 5527 e da ADPF 403). Tem como objetivos estudar o processo de construção do marco regulatório da Internet no Brasil e compreender como os debates legislativos são recepcionados no plano do Judiciário. Trata-se de pesquisa quanti-qualitativa: parte-se da apresentação de algumas referências sobre a regulação da Internet, foco da análise da atuação dos atores, apresenta-se os pontos de conexão (semelhanças e divergências) entre seus argumentos e como, no Legislativo e Judiciário, esses atores envidaram esforços na implementação de seus interesses. A conclusão refere-se à importância da regulação da Internet como forma de garantia e proteção de direitos fundamentais.

PALAVRAS-CHAVE: regulação; internet; atores; Marco Civil da Internet.

\footnotetext{
' Universidade de Brasília, Laboratório de Políticas Públicas e Internet (LAPIN), Brasília, DF, Brasil, ORCID; ii Universidade de Brasília, Programa de Pós-Graduação em Direito, Brasília, DF, Brasil, ORCID; iii Universidade de Brasília, Faculdade de Direito, Brasília, DF, Brasil, ORCID.
} 


\title{
DEVELOPMENTS IN INTERNET REGULATION: THEORETICAL MODELS AND ACTORS INVOLVED
}

\author{
Amanda Nunes Lopes Espiñeira Lemos \\ Ana Cláudia Farranha \\ Isaac Reis
}

\begin{abstract}
This paper maps the actors involved in the regulation of the Brazilian Internet, from the public hearings held in the National Congress, at the time of the elaboration of Brazilian Civil Rights Framework for Internet and in Brazilian Supreme Court in the scope of actions that question the constitutionality of the provisions of this regulatory framework (ADI 5527 and ADPF 403). It aims to study the process of building the Internet's regulatory framework in Brazil and understand how legislative debates are received at the Judiciary level. This is quanti-qualitative research: it starts with the presentation of some references on Internet regulation, the focus of the analysis of the actors' performance, the connection points (similarities and divergences) between their arguments and how, in the Legislative and Judiciary, these actors have made efforts to implement their interests. The conclusion refers to the importance of Internet regulation as a way of guaranteeing and protecting fundamental rights.
\end{abstract}

KEYWORDS: regulation; internet; actors; Brazilian Civil Rights Framework for Internet. 


\section{INTRODUÇÃO}

O processo regulatório é composto por distintos interesses em disputa que se refletem na construção legislativa. As audiências públicas, realizadas no âmbito do Poder Legislativo, são arenas de discussão relevantes por envolver múltiplos atores e, assim, influenciam no processo regulatório. Esse processo também se perpetua em outras arenas de decisão política, como na interpretação de um marco regulatório, pelo Judiciário, ou mesmo na discussão da constitucionalidade das leis.

O objetivo deste trabalho é mapear os atores envolvidos na regulação da Internet brasileira a partir das quatro audiências públicas realizadas pela Comissão Especial no Congresso Nacional, à época da elaboração do Marco Civil da Internet - MCI (Lei n 12.965/2014), e da audiência pública realizada no Supremo Tribunal Federal (STF) no âmbito da ADI 5527 e da ADPF 403, que questionaram a constitucionalidade de dispositivos no $\mathrm{MCl}$. Esse objetivo desdobra-se na compreensão acerca de como os debates legislativos são recepcionados no plano do Judiciário. Eles espelham argumentos da mesma compreensão (legislativo) ou são reformulados na arena decisória sobre sua constitucionalidade? Para tanto, cabe identificar os atores que participaram dessas audiências públicas (no Legislativo e no Judiciário) e quais os pontos de conexão (semelhanças e divergências) entre esses atores e os seus respectivos argumentos. Trata-se de uma tentativa de compreender discursos nas áreas das audiências públicas no marco dos dois poderes. O artigo está dividido em três partes. Na primeira, apresenta-se alguns referenciais internacionais da regulação da Internet, como pressuposto teórico para a segunda parte, na qual se analisa o modelo brasileiro de regulação da Internet. Busca-se apresentar um pano de fundo sobre o tema da 
regulação da Internet, iniciando com a apresentação de algumas das teorias acerca do tema. A terceira e última parte contém a sistematização e análise dos atores envolvidos na regulação da Internet e seus respectivos argumentos, ressaltando-se as convergências e divergências de seus interesses.

\section{METODOLOGIA}

Metodologicamente, trata-se de pesquisa quanti-qualitativa (Minayo, 2007) tomando como universo os atores escolhidos nas cinco audiências analisadas. Como suporte à análise empírica, a partir das audiências públicas analisadas, utiliza-se a ferramenta Rawgraphs para construção dos gráficos, dendrogramas e circle packing, utilizados como Figuras ilustrativas da pesquisa neste trabalho.

Nesse sentido, realizou-se do ponto de vista qualitativo, os seguintes passos: a) o acompanhamento presencial no STF, com observação não participante;

b) a leitura das atas e a visualização de vídeos da íntegra das audiências públicas do Congresso Nacional, com degravações e tabulação de dados;

c) a classificação dos atores das audiências, multissetorialmente em 4 (quatro) categorias da Governança da Internet: Sociedade Civil, Governo, Setor Privado e Comunidade Técnico-Científica;

d) a análise com base no conceito operacional de grupos de interesse (Calmon \& Da Costa, 2007; Vianna, 1994) e nas teorias da regulação da Internet (Lessig, 2006; Murray, 2011);

A análise quantitativa subsidiou a qualitativa, uma vez que mostra a distribuição dos atores, em termos percentuais, nos momentos distintos do debate anterior e posterior ao $\mathrm{MCl}$. Parte-se de uma revisão bibliográfica para o 
aprofundamento teórico sobre a regulação da Internet a partir da compreensão deste fenômeno como uma questão técnico-política.

Ademais, o aprofundamento das análises realizadas foi facilitado pela inserção no campo de pesquisa, com a participação em outros espaços que contaram com discussões semelhantes às audiências objeto deste trabalho e com a presença de atores que participaram também das audiências analisadas, como Escolas de Governanças, Minicursos, Seminários, Fóruns e Congressos no tema da Governança da Internet.

\section{A REGULAÇÃO DA INTERNET COMO QUESTÃO TÉCNICA E POLÍTICA}

A regulação da Internet pode ser compreendida como a normatização ou determinação de condutas e valores para o uso da rede, não apenas em seus componentes de aplicação e aplicativos, mas também nos protocolos e na infraestrutura técnica envolvidos no seu funcionamento. Essa concepção está inserida na noção maior de Governança da Internet, que deve ser baseada em princípios, como a proteção da privacidade, a garantia da liberdade de expressão, a neutralidade da rede e a preservação da sua natureza participativa (Bauer, 2007), dentro de uma perspectiva multissetorial.

No panorama internacional, existem algumas teorias que abordam modelos distintos de regulação do ciberespaço, diante das implicações das novas tecnologias para as relações jurídicas. Essas teorias estão diretamente relacionadas com o contexto histórico-político no qual foram desenvolvidas.

Um dos principais modelos teóricos encontra-se centrado na ordenação espontânea do ciberespaço, exemplificado na declaração da liberdade da Internet, mais conhecida como cyber-libertarianismo (Barlow, 1996), para o qual a Internet está acima das jurisdições e dos espaços territoriais. Esse modelo baseia-se em dois princípios bastante relevantes para a compreensão da regulação: a desregulamentação dos bits e a capacidade dos usuários de transcender fronteiras 
sem desafios. Importa ressaltar que o trabalho de Barlow foi escrito em um momento histórico distinto do atual, em que a Internet era muito diferente: havia menos aplicações na camada de conteúdo’ e os dilemas regulatórios eram outros e menos complexos.

Uma corrente teórica contrária ao cyber-libertarianismo foi o cyberpaternalismo, que possuía Joel Reidenberg (1996) como representante, sendo-Ihe atribuído o conceito de Lex informatica. Essa corrente teórica identificou dois tipos de sistemas regulatórios privados: (1) regimes baseados em acordos contratuais, como aqueles entre provedores de Internet (Internet Service Providers - ISPS) e clientes; e (2) regimes baseados na arquitetura de rede, como os padrões técnicos promulgados por órgãos como a IETF (Internet Engineering Task Force). Reidenberg demonstrou como esses sistemas poderiam, por meio da aplicação de controle de projeto, agir como procuradores para os tribunais e as autoridades policiais (Murray, 2007, p. 8). Esse modelo foi contestado por "cyberlawyers" como Cass Sustein (2001) e Lawrence Lessig (1999), os quais demonstraram limitações regulatórias no modelo cyber-paternalista.

O quadro abaixo (Quadro 1) expõe os detalhes dos dois principais modelos teóricos clássicos e antagônicos da regulação da Internet, e facilita a compreensão das teorias mais modernas que serão delineadas.

\section{Quadro 1}

Modelos Clássicos da regulação da Internet

\section{Cyber-liberatarianismo Cyber-paternalismo}

\begin{tabular}{lll}
\hline Objeto & $\begin{array}{l}\text { Centrado na ordenação } \\
\text { espontânea }\end{array}$ & "Lex Informatica" \\
ciberespaço & & \\
Princípios & 1) Desregulamentação & 1) Regimes baseados em \\
& dos bits; & acordos contratuais; \\
\hline
\end{tabular}

\footnotetext{
'A Internet, de forma simplificada, pode ser subdividida em três camadas, que representam a cadeia de valor do acesso à rede. A primeira delas é a camada de infraestrutura, que corresponde a toda a parte técnica da Internet, incluindo basilarmente o serviço de telecomunicações. Há a camada lógica, que envolve nomes de domínio e os serviços de conexão. E por fim, a camada de conteúdo, que corresponde à camada das aplicações, à qual os usuários têm acesso e utilizam-se do serviço de informações.
} 


\begin{tabular}{lll}
\hline 2) Capacidade dos & 2) Regimes baseados na \\
usuários da Internet de & arquitetura de rede. \\
transcender fronteiras & \\
sem desafios. & Barlow (1996) & Reidenberg (1996) \\
Principal teórico & &
\end{tabular}

Fonte: Produzido pelos autores.

Outro modelo é baseado no código, tendo em Lessig (2006) o seu principal teórico. O autor procura identificar os quatro principais modelos de regulação: pela lei ou Direito, pelo mercado, pela arquitetura ou infraestrutura da Internet e pelas normas sociais amparadas na construção de valores, para além do modelo da regulação realizado por organizações transnacionais e internacionais, conforme a representação abaixo.

\section{Figura 1}

Modelo regulatório Lawrence Lessig

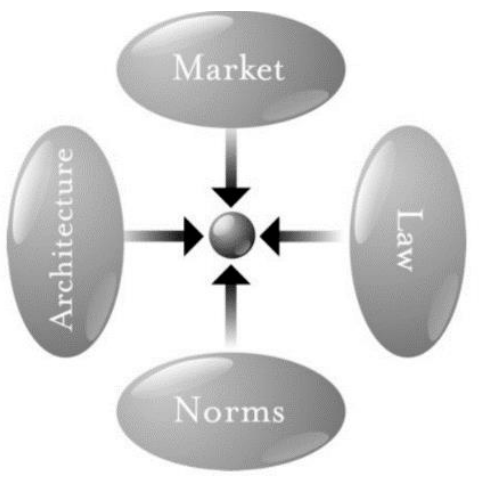

Fonte: Lessig, 2006, p.123.

Andrew Murray (2007), por sua vez, propõe um modelo de regulação mais flexível para a Internet, considerando a complexidade do ciberespaço a partir de uma estrutura regulatória mais abrangente, com o conceito de comunitarismo em rede, conforme a representação abaixo extraída de artigo do autor:

\section{Figura 2}

Modelo regulatório Andrew Murray 


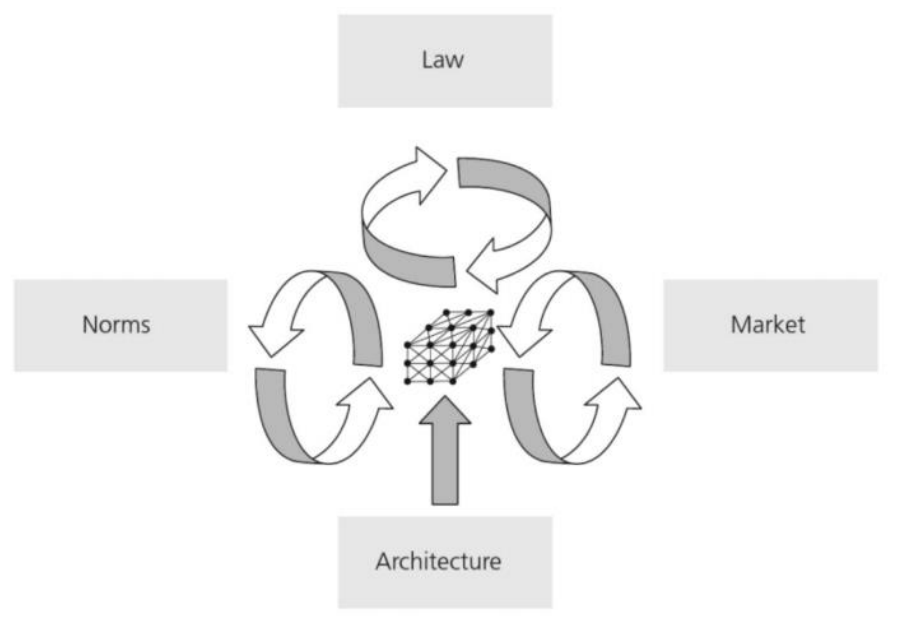

Fonte: Murray, 2011. p. 195-221.

Outro modelo teórico é produzido por Laura Denardis (2013), que compreende a regulação da Internet como uma questão político-técnica, em que se deve perceber a interrelação e a influências dos aspectos da infraestrutura nas relações sociais. Nesse sentido este trabalho adota a proposta de regulação "by design", apresentada por Laura Denardis em obra organizada junto com Francesca Musiani e outros (Musiani, Cognurn, Denardis \& Levinson, 2016), para os quais concepções políticas são pensadas desde a elaboração da infraestrutura, no nível técnico.

A apresentação destas visões regulatórias nos coloca uma questão: qual a perspectiva de regulação adotada nos processos relativos às audiências públicas em análise nesse trabalho? Para concluir, toma-se como parâmetro a versão adotada por Vermeule (2016). O autor demonstra que a relação entre o Estado Administrativo e a supremacia da lei evidencia a posição relativa do Judiciário frente à regulação. Nesse contexto, o diálogo entre teorias da regulação e da argumentação mostra-se relevante para melhor analisar os argumentos proferidos em ambos os processos deliberativos que resultaram na tomada de decisão legislativa e acarretarão na decisão judicial, ambos tratando do Marco Civil da Internet. Entende-se que a tomada de decisão é o momento final no processo de interpretação jurídica e, para tanto, é importante compreender ambos os processos do ponto de vista argumentativo. No entanto, não de maneira isolada 
do discurso em si mesmo, antes o situando em um contexto regulatório sobre o tema da Internet, a nível nacional e internacional, sob o prisma não apenas jurídico, mas também político e técnico.

Nesse sentido, Soares destaca:

O fenômeno regulatório não pode ser visto de maneira isolada e unidirecional a partir do Estado (state-centered). Deve focar no contexto social (society-centered), segundo a dinâmica das múltiplas interações ocorridas no espaço regulatório (regulatory space) ou nas muitas arenas de discussão (many rooms), dentre elas o Poder Judiciário, também apontado como um ator do processo político. (Soares, 2016, p. 10)

Ao trazer diversos stakeholders que defenderão questões técnicas, como a criptografia no caso do bloqueio do WhatsApp ou mesmo a neutralidade de rede na discussão do $\mathrm{MCl}$, dentro desse ambiente jurídico-político com uma pluralidade de interesses tanto convergentes como conflitantes, o Supremo Tribunal Federal e o Legislativo Federal proporcionaram arenas de discussão para tratar desses processos sócio-técnicos que impactam na regulação da rede.

Apresentam-se, a seguir, elementos sobre o processo de construção regulatória da Internet no Brasil no Congresso Nacional, inicialmente, e também no espaço de deliberação ocorrido no STF, de modo a contextualizar as análises feitas no tópico seguinte.

\section{O PROCESSO DE CONSTRUÇÃO LEGISLATIVA DO MODELO REGULATÓRIO DE INTERNET BRASILEIRO}

O Brasil assumiu um papel de destaque em relação à regulação da Internet, com a aprovação do Marco Civil (Lei no 12.965/2014) e, posteriormente, com a publicação do Decreto Regulamentador $n^{\circ}$ 8.771/2016. O protagonismo brasileiro na aprovação do Marco Civil e o processo participativo de construção dessa lei impulsionaram o debate entre as diversas partes afetadas pela regulação da rede no país. Antes dele, não havia uma regulamentação específica e a Internet era regida apenas pela Lei Geral de Telecomunicações (Lei nº 9.472/1997). 
O Ministério da Justiça começou a trabalhar em uma minuta de Projeto de Lei (PL) para substituir o PL proposto pelo senador Eduardo Azeredo, que possuía um caráter punitivo de condutas praticadas na rede. A responsabilidade de redação ficou a cargo da Secretaria de Assuntos Legislativos (SAL) do Ministério da Justiça (MJ), que passou a se reunir com os movimentos ligados à pauta. Em parceria com o Centro de Tecnologia e Sociedade (CTS) da Fundação Getúlio Vargas, do Rio de Janeiro (FGV-RJ), a SAL começou a estruturar o anteprojeto do Marco Civil. (Nolasco, 2014, p. 59; Rená, 2010, p. 97)

O PL n²126/2011, que gerou o Marco Civil da Internet (Lei $n^{\circ} 12.965 / 14$ ), em seu processo de elaboração, passou por diversos processos participativos. Optouse pela realização de consulta pública de formato inovador: em duas fases, sendo a primeira realizada, em 2009, por meio de um blog aberto a comentários e da utilização da rede social Twitter. A segunda etapa de consultas públicas, contou com o blog aprimorado e a possibilidade de comentários e visualização do debate relativo a cada dispositivo da lei. Para Pedro Abramovay, então Secretário da SAL, a ideia de a consulta ser realizada por meio de ferramentas digitais se deu porque acreditava-se ser necessário fazer um debate amplo com a sociedade. (Nolasco, 2014, p. 64; Rená, 2010, p. 101; Bragatto et al. 2015).

O debate em torno do Marco Civil da Internet atraiu a sociedade civil e a comunidade de especialistas sobre o tema. Dessa forma, acumularam-se, no total, 1.168 comentários, além de incontáveis manifestações pelo Twitter e de várias menções em blogs e notícias. (Rená, 2010, p. 101).

O processo de consulta pública prolongou-se até maio de 2010 , quando o Ministério da Justiça passou a trabalhar na redação final do Projeto de Lei, que em 24 de agosto de 2011, fosse enviado pela Presidenta Dilma Rousseff à Câmara dos Deputados. Em março de 2012, foi instalada uma comissão especial destinada a analisar o Projeto de Lei que criaria o Marco Civil da Internet. O relator, Alessandro Molon, apresentou dois relatórios para o projeto (Nolasco, 2014, p. 70).

Antes de apresentar os relatórios, contudo, o Relator convocou a realização de audiências públicas em seis capitais com setores interessados, reunindo palestrantes e especialistas no tema. As audiências aproveitaram o mapeamento 
das posições das consultas públicas do anteprojeto da Lei (Cruz, 2015, p. 91). Além disso, o projeto de lei também foi disponibilizado na plataforma E-Democracia, da Câmara dos Deputados², para receber comentários e propostas de alteração dos usuários da rede, algumas abarcadas pelo substitutivo em 2012. (Cruz, 2015, p. 92)

No dia 11 de setembro de 2013, a presidenta Dilma Rousseff designou regime de urgência constitucional na votação do Marco Civil da Internet, quando começou a contagem de 45 dias para que os deputados apreciassem o projeto de lei. Como isso, não ocorreu em dezembro de 2013; o marco regulatório trancou a pauta do Congresso e foi votado em 2014. (Nolasco, 2014, p. 71). Nesse sentido, Calmon et al. (2007, p. 6) abordam o papel dominante que um presidente pode ter formação da agenda governamental como difusores de ideias.

A preocupação com o tema da regulação da Internet no Brasil se deu com o vazamento de informações da Agência de Segurança Nacional dos USA (NSA), por Edward Snowden, ex-funcionário da agência governamental americana, que denunciou vigilância em massa na Internet. Além do chamado "efeito Snowden", também impulsionaram as discussões do $\mathrm{PL} \mathrm{n}^{\circ} 2.126 / 2011$, como uma resposta legislativa, a negociação política com lobbies corporativos preocupados com as perdas que a proteção de direitos dos usuários da rede poderia ocasionar e a aprovação do PL n 2.793/2011, conhecida como "Lei Carolina Dieckmann", gerada por conta da comoção em torno do vazamento de fotos íntimas da atriz (Cruz, 2015, p. 94).

Há, então, uma influência do ator Governo na formação da agenda do $\mathrm{MCl}$ e o papel da Presidenta influenciando a pauta legislativa e regulatória. Assim, uma questão importante para pensar como esses discursos se colocam na arena interpretativa do Judiciário é compreender como ao interpretar o $\mathrm{MCl}$ e decidir, os juízes podem tomar para sim um papel relevante na política pública das comunicações e da Internet. Ao decidir sobre a constitucionalidade dos dispositivos

\footnotetext{
${ }^{2}$ Acesso pelo site: http://arquivo.edemocracia.camara.leg.br/web/marco-civil-dainternet/inicio\#.W2D7J9JKjIU
} 
do MCl, nas ações ADI 5527 e ADPF 503 seria o STF também um ator no processo regulatório?

Relevante lembrar também que "tão importante quanto os atores do Governo são os não governamentais, ainda que não disponham de tantos recursos para interferir na agenda de políticas públicas" (Calmon \& Da Costa, 2007, p. 6). Aqui estaria representada a sociedade civil que, muitas vezes formadas por ONGs, não dispõem de tanto capital para mobilização.

Mancuso (2004) demonstra a importância dessa articulação de interesses a partir de um estudo do sucesso do lobby do setor industrial, a partir da ação política para implementação de políticas públicas que o setor julga necessárias para seus interesses e na redução de custos. Posner (1975) em uma literatura clássica apresenta essa ideia de custos e interesses privados via regulação que se mostram fundamentais nessa análise de grupos de interesses. No âmbito das audiências públicas aqui analisadas, tem-se claro 0 interesse das empresas de telecomunicações e a disputa pelo tema da regulação da Internet. Não foi objeto deste trabalho aprofundar o tema sobre lobby, entretanto essa literatura nos auxilia a apresentar os grupos identificados nos espaços escolhidos para análise (audiências públicas anterior e posterior ao $\mathrm{MCl}$, no Legislativo e Executivo) e a mapeá-los a partir da compreensão multissetorial da Governança da Internet

Além disso, "a importância dos grupos de interesse é mais reconhecida quando esses se integram a um debate já existente. O poder de interferir nas eleições é uma função do número de indivíduos que os grupos representam e conseguem mobilizar, além da sua dispersão geográfica e influência" (Calmon \& Da Costa, 2007, p. 6). Os autores mostram como a coesão é um elemento fundamental dentro dos grupos de interesse, para que se forme uma coletividade e a mobilização seja possível e a influência seja maior, inclusive abrangendo litígios judiciais, que no contexto desta pesquisa poderia ter como exemplo as ações constitucionais analisadas, a ADI 5527 e a ADPF 403.

Nesse cenário, outro ator importante a Comunidade Técnica é o segundo grupo de interesse mais importante. Já que "por se tratar de um grupo especializado em determinadas questões, os mesmos possuem maior capacidade 
de influir nas alternativas consideradas para uma política do que na formação da agenda, que só influenciam no longo prazo". (Calmon \& Da Costa, 2007, p. 6)

Destaca-se também a finalidade e as intenções legislativas do Marco Civil da Internet para melhor compreender como interpretá-lo:

Nesse contexto, o escopo do Marco Civil da Internet estaria em criar uma camada de interpretação entre a Internet e o direito, que permitisse exigir a observação de normas que positivassem a compreensão da rede mundial como um espaço que extrapola as fronteiras nacionais de comunicação e se estrutura pelo compartilhamento de informações, fundado em protocolos abertos e com a governança mundial. Nesses termos, essa interface jurídicotecnológica seria essencial para que a aplicação das normas legais pudesse identificar os limites adequados. (Rená, 2010, p.103)

Assim, o modelo que o $\mathrm{MCl}$ propõe baseia-se em princípios que refletem numa construção legislativa colaborativa e participativa (Solagna, 2015; Cruz, 2015; Rená, 2010) a qual envolve consultas e audiências públicas com representantes de diversos setores e regiões do país. O ambiente de participação se perpetua com a convocação da audiência pública no STF para tratar dos casos de bloqueios de WhatsApp. A fim de compreender esses dois momentos, anterior e posterior ao $\mathrm{MCl}$, escolhem-se as audiências públicas como objeto de estudo.

Dessa forma, tomando como base atores no processo regulatório da rede, com distintos interesses, a fim de compreender os espaços de participação que contribuíram para a regulação da Internet brasileira, analisa-se as audiências públicas que fizeram parte desse processo.

\section{SISTEMATIZAÇÃO DE ATORES ENVOLVIDOS NA REGULAÇÃO DA INTERNET}

Nesta seção, mapeia-se os atores envolvidos nas audiências públicas realizadas pela Comissão Especial no Congresso Nacional, à época da elaboração do Marco Civil da Internet (Lei n 12.965/2014) e da audiência pública realizada no STF no âmbito da ADI 5527 e ADPF 403, que questionam a constitucionalidade de dispositivos no $\mathrm{MCl}$. 
As audiências públicas analisadas sobre o processo legislativo foram realizadas no Congresso Nacional, em todo processo de elaboração e análise da Proposta Legislativa do PL n 2126/2011, isto é, em momentos distintos desde 2010 até 2013, já que foi aprovado em 2014. Os títulos e datas das audiências podem ser vistos no quadro abaixo (Quadro 2).

\section{Quadro 2}

Audiências Marco Civil da Internet no Congresso Nacional

\begin{tabular}{|c|c|}
\hline Título & Data \\
\hline $\begin{array}{l}\text { O Marco Civil da Internet } \\
\text { no Brasil }\end{array}$ & $27 / 04 / 2010$ \\
\hline Marco Civil da Internet & 17/04/2012 \\
\hline $\begin{array}{l}\text { O Marco Civil da Internet } \\
\text { no Brasil }\end{array}$ & 07/08/2013 \\
\hline $\begin{array}{l}\text { Marco Civil da Internet - } \\
\text { Comissão Geral }\end{array}$ & $06 / 11 / 2013$ \\
\hline
\end{tabular}

Fonte: Produzido pelos autores.

Também foi analisada a audiência, ocorrida em 2017, que discutiu no STF o bloqueio judicial do WhatsApp e o Marco Civil da Internet. A decorrência do tempo entre a realização das audiências contribuirá na demonstração da evolução desse percurso regulatório, com o momento anterior, a partir do processo legislativo, e posterior à vigência do Marco Civil da Internet e os atores que o compõem.

Os atores identificados são então classificados de acordo com o parâmetro da Agenda Tunis, Declaração NETmundial ${ }^{3}$ (classificação multissetorial). Eles foram separados entre quatro principais categorias: (1) "Governo": que

\footnotetext{
${ }^{3} \mathrm{~A}$ Declaração NETmundial é o produto gerado como resultado de um encontro multissetorial global sobre o futuro da governança da Internet ocorrido em São Paulo, Brasil nos dias 23 e 24 de abril de 2014 , organizado pelo CGI.br e a 1 Net. Este encontro reuniu 1.480 representantes de diferentes atores, com diversidade de 97 países, como foco a elaboração de princípios de governança da Internet e a proposta de um roteiro para a evolução futura do ecossistema de governança da Internet. Assim, o evento constituiu um marco que demonstrou a importância do modelo colaborativo multissetorial, participativo e democrático na construção da regulação e da governança da Internet. Todas as informações sobre o mesmo constam no site http://netmundial.br/pt/.
} 
compreende representantes de um dos três poderes - Executivo, Legislativo e Judiciário; (2) "Setor privado ou empresarial": que compreende os atores com atuação no eixo econômico (mercado) com finalidade lucrativa; (3) "Sociedade Civil ou Terceiro Setor" (ente privado): são as ONG, OSC, OSCIP com ausência de fins lucrativos; e (4) "Comunidade Técnica e acadêmica ou científica e tecnológica": envolvem as universidades, os grupos de estudo e pesquisa e pesquisadores da área técnica. A distinção do documento "Declaração Multissetorial" consiste em envolver a comunidade acadêmica e os órgãos de pesquisa, mesmo de temas de policy, dentro de comunidade técnica e não da Sociedade Civil.

Dessa forma, a classificação dos atores envolvidos nas cinco audiências analisadas é feita de maneira categorizada e sistematizada pela metodologia acima adotada, levando em consideração as instituições participantes, o partido político dos deputados envolvidos e o gênero dos participantes. Além de uma análise comparativa entre os participantes desses espaços de deliberação e participação social no contexto da regulação da Internet nacional, trabalha-se com a sistematização dos dados em gráficos.

\section{Figura 3}

Gráfico Ator por audiência 


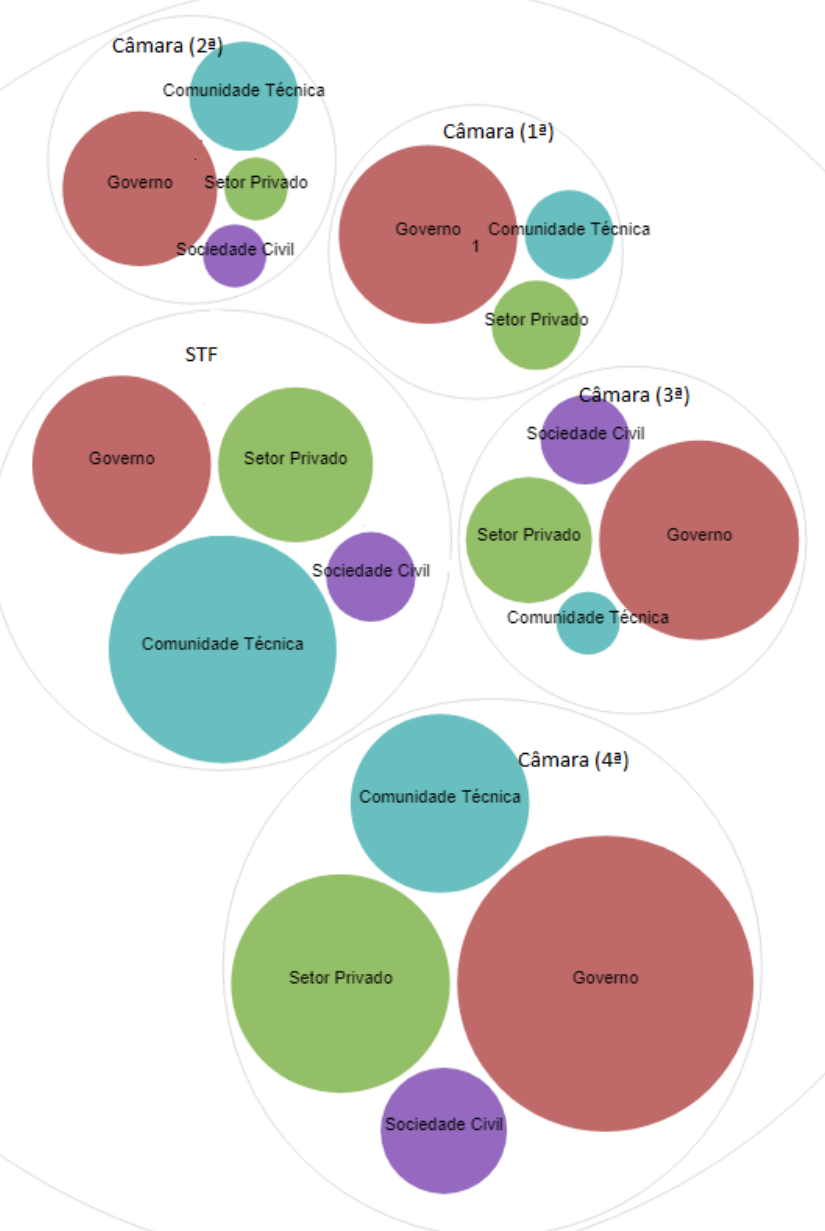

Fonte: Produzido pelos autores.

O Gráfico (Figura 3) apresenta qual ator foi mais ativo em cada audiência. Dessa maneira, quanto maior o círculo, maior será a participação. O Governo teve maior protagonismo em todas as audiências ocorridas na Câmara dos Deputados, enquanto a Comunidade Técnica apresentou maior participação na audiência do STF, no momento posterior ao Marco Civil da Internet. A Sociedade Civil, ou Terceiro Setor, é o ator que menos apareceu nos debates.

Abaixo, o Gráfico (Figura 4), apesar de conter informações do Gráfico (Figura 3), as complementa, uma vez que no seu anel interno demonstra qual ator foi mais participativo em todas as audiências, enquanto no externo revela em qual audiência cada ator teve maior participação.

\section{Figura 4}




\section{Gráfico Distribuição de atores}

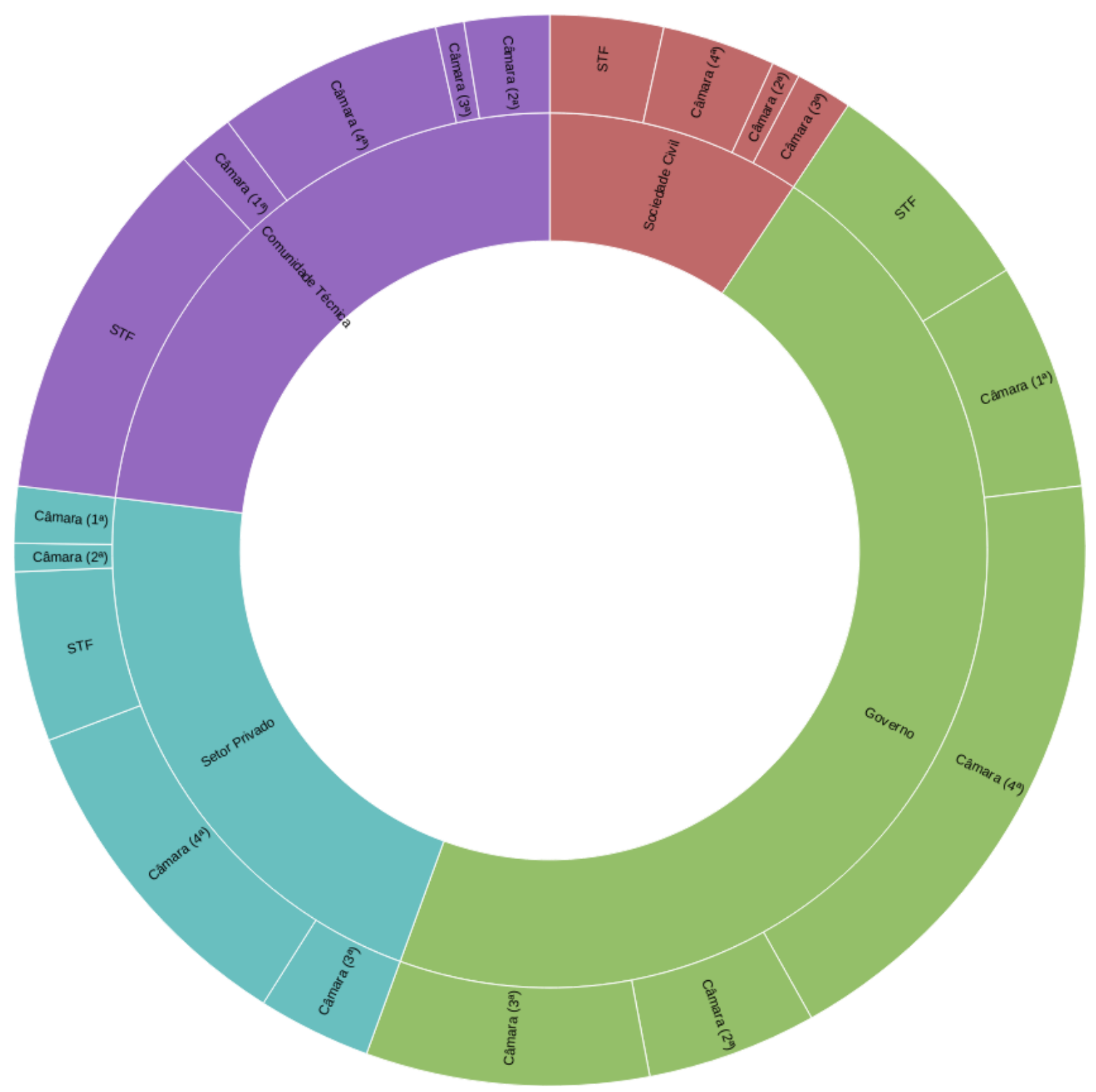

Fonte: Produzido pelos autores.

Diante disso, na primeira audiência predominou a presença de representantes do Governo. Em um total de 12 participantes, 8 eram do Governo (66,66\%), enquanto Setor Privado e a Comunidade Técnica estavam com 2 representantes cada (16,67\%). Não houve representantes do Terceiro Setor, o que 
demonstra a ausência de uma organização estruturada da Sociedade Civil nessa pauta logo no início e evidencia seu respectivo crescimento depois.

Já na segunda, no total de 11 participantes o Governo possui pouco mais da metade, com 6 participantes (54,54\%), o Setor Privado em segundo lugar com 3 participantes (18,18\%) e em seguida a Sociedade Civil e Comunidade Técnica com 1 representante cada $(9,09 \%)$.

A terceira audiência anterior ao Marco Civil da Internet contou com 10 representantes do Governo (58,82\%), 4 do Setor Privado (23,52\%), 2 da Sociedade Civil (11,77\%) e em último lugar a Comunidade Técnica com 1 representante (5,88\%) em um universo de 17 participantes.

A quarta, e última, audiência na Câmara possuiu um total muito maior do que as demais realizadas no Congresso Nacional anterior ao $\mathrm{MCl}$, com 46 participantes, grande parte deles parlamentares, sendo 22 do Governo (47,82\%), 12 do Setor Privado (26,08\%), 8 da Comunidade Técnica $(17,39 \%)$ e por último a Sociedade Civil com 4 representantes (8,69\%).

Por sua vez, no STF, a Comunidade Técnica possuiu a maior quantidade de representantes: no total de 29 participantes, 13 representavam esse setor (44,82\%). Esse fato decorre da necessidade de ouvir e discutir sobre elementos técnicos do tema, o que pesquisadores e estudiosos sobre o tema desde a área da infraestrutura até elementos regulatórios, poderiam contribuir melhor. Além disso, do universo total de participantes, 8 representavam o Governo (27,58\%), 6 o Setor Privado (20,68\%) e a Sociedade Civil em minoria apenas com 2 representantes (6,89\%).

No total das seções, 115 participantes, sendo 54 (46,95\%) representantes do Governo, o que envolve parlamentares nas primeiras 4 audiências, 27 da Comunidade Técnica (23,47\%), 25 do Setor Privado (21,73\%) e 9 da Sociedade Civil (7,82\%).

Os números demonstram a distribuição dos participantes das quatro categorias acima escolhidas e atribuídas aos atores nos dois momentos, anterior e posterior ao $\mathrm{MCl}$. Essa identificação e classificação de atores servem para testar a hipótese de que as dinâmicas do parlamento e do Judiciário são distintas no uso 
do mesmo instrumento: a audiência pública. Embora haja uma ressignificação do tema da regulação para uma dimensão técnica no STF, ela continua atrelada à política e mantém a sua relevância. Trata-se também um mapeamento de como os atores, e aqui os interesses representados, e os poderes se articulam em relação à política de Internet.

Uma vez analisadas a porcentagem que representa as categorias dos atores e a distribuição dos atores nas cinco audiências é importante também compreender por quais instituições esses atores são representados, a partir de uma análise comparativa entre esses espaços de participação sob o prisma anterior e posterior ao Marco Civil.

\subsection{CONVERGÊNCIAS E DIVERGÊNCIAS DE INTERESSES E DISCURSOS DOS ATORES ENVOLVIDOS EM MOMENTO ANTERIOR E POSTERIOR AO MCI}

O Dendrograma (Figura 5) abaixo mostra todas as instituições que participaram dos debates com a respectiva relação destas instituições com os atores que fazem parte e elucida a questão: Quais os principais atores que participaram dessas audiências públicas (no Legislativo e no Judiciário) e quais os pontos de conexão (semelhanças e divergências) entre esses atores e os seus respectivos argumentos? Percebe-se que o Setor Privado e a Comunidade Técnica são os atores com maior número de instituições representadas no debate, apesar de o Governo ter tido maior participação em termos quantitativos e percentuais como se demonstrou nos Gráficos acima. Isso se deve ao fato de a maior parte das instituições do Governo se repetir.

O mesmo ocorre com a Sociedade Civil, que, apesar de ter poucos representantes, também possui proporcionalmente poucas instituições que a representam. Grandes partes dessas instituições da Sociedade Civil, posteriormente, nos debates da Câmara, em 2016 se uniram e formaram a chamada Coalizão de Direitos na $\mathrm{Rede}^{4}$, um grupo que participa ativamente no

\footnotetext{
${ }^{4}$ Acesso pelo site: https://direitosnarede.org.br/
} 
Congresso Nacional no processo de advocacy para proteção dos direitos dos usuários da Internet, com diversos projetos de conscientização tanto dos parlamentares como dos próprios internautas, como a campanha "Seus Dados são Você".

\section{Figura 5}

Dendrograma de Distribuição de Instituições

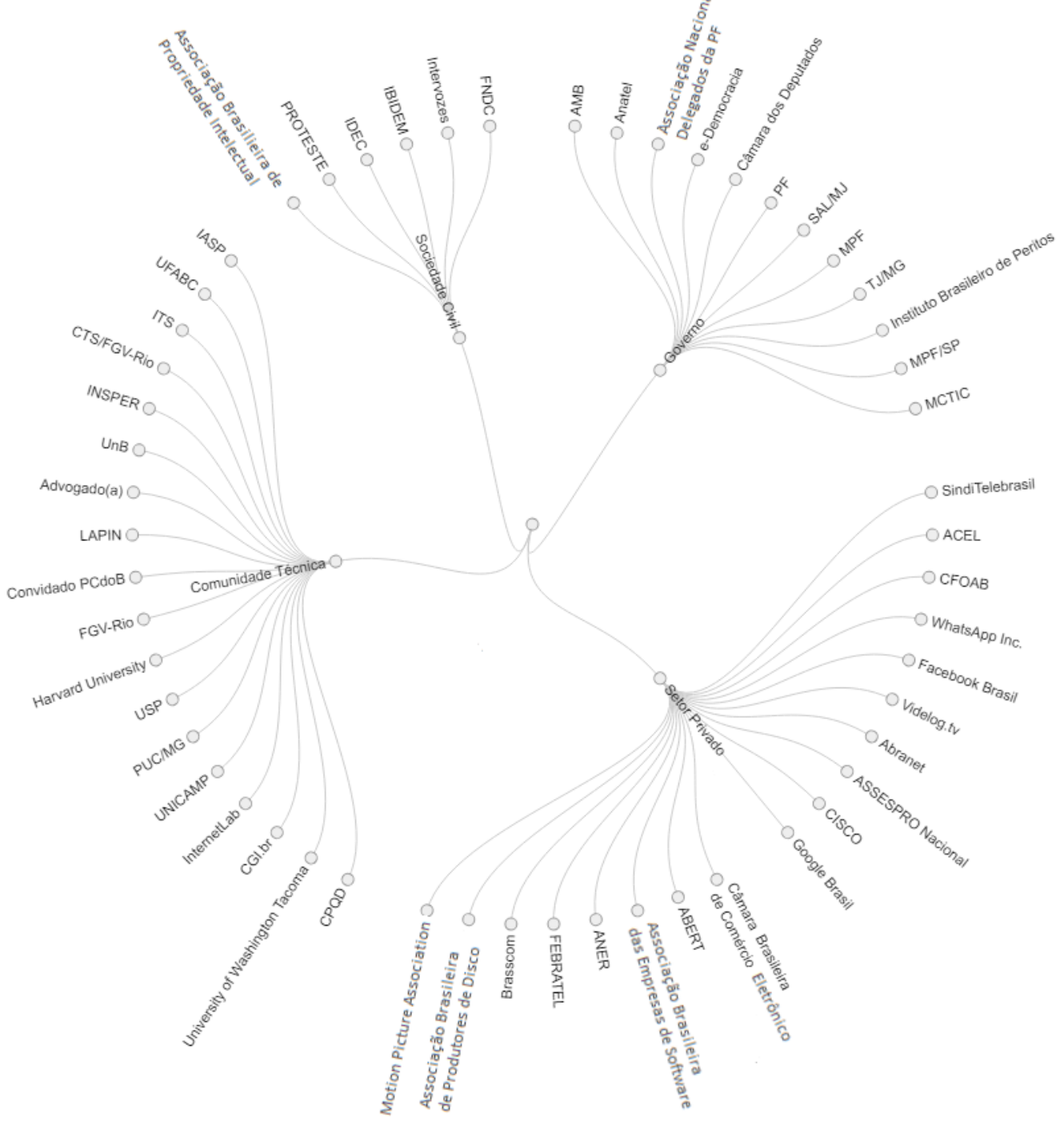

Fonte: Produzido pelos autores 
O Dendrograma, contudo, não demonstra a incidência da participação das instituições, assim se complementa no Gráfico (Figura 6), abaixo, que apesar de também representar as instituições divididas por atores, demonstra a proporção de participantes de cada uma delas sobre o total. Quanto maior o círculo, maior a quantidade de participantes de cada uma das instituições.

\section{Figura 6}

\section{Gráfico Participação de Instituição por ator}

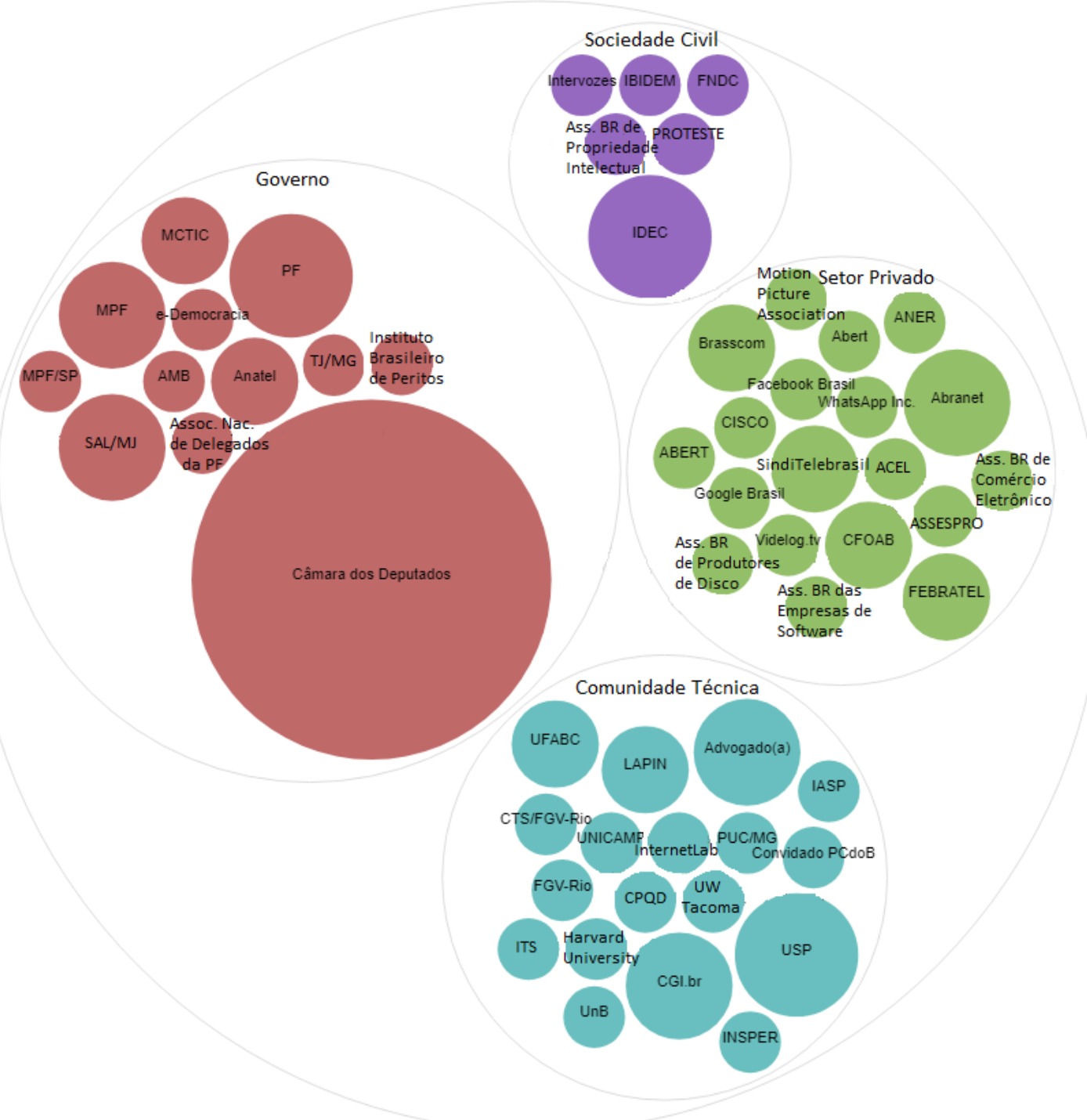

Fonte: Produzido pelos autores 
O Gráfico (Figura 6) apresenta os atores por instituições representadas. Da sua leitura é possível identificar que o IDEC foi a instituição da Sociedade Civil com maior participação. As demais 5 cinco instituições aparecem com proporções semelhantes, o que demonstra paridade na participação entre elas, quais sejam: IBIDEM, PROTESTE, FNDC, Intervozes e Associação Brasileira de Propriedade Intelectual.

Já em relação ao ator Governo, a Câmara dos Deputados é a protagonista, tendo sido a Casa que abrigou as audiências anteriores ao $\mathrm{MCl}$. Ademais a SAL do $\mathrm{MJ}$, que propôs a primeira versão do $\mathrm{PL}$ do $\mathrm{MCl}$ também aparece com maior incidência de participação. Do mesmo modo o MPF e a PF, estes diretamente interessados na discussão posterior ao $\mathrm{MCl}$ de bloqueio do aplicativo WhatsApp e na possibilidade de contornos regulatórios influenciarem suas atividades investigativas. Nota-se então que a Câmara dos Deputados foi a instituição com maior representatividade no ator Governo. A participação dos parlamentares apesar de majoritária, outras instituições também são mais atuantes nesse ator, como a Polícia Federal, o MPF, a SAL do MJ, o MCTIC e a Anatel.

O Setor Privado teve representação mais contundente pela ABRANET, FEBRATEL E BRASSCOM. Todas as instituições que representam um conjunto de instituições (Associações) com interesse nos temas da neutralidade da rede e da responsabilização dos provedores como intermediários, debate travado na discussão anterior ao $\mathrm{MCl}$. Outro fenômeno que se percebe é a representatividade de alguns participantes do Setor Privado para instituições distintas ao longo do período analisado.

O mesmo fenômeno ocorre entre a Sociedade Civil e a Comunidade Técnica, em que alguns participantes acabam possuindo representatividades distintas, já que muitos dos que atuam nos temas da Governança e regulação da Internet são também estudiosos e pesquisadores.

Em relação à Comunidade Técnica, o CGl.br é uma das instituições com maior participação, junto à UFABC e à USP, pelas instituições de pesquisa que a Universidade abriga sobre temas de Internet, sobretudo em relação à elementos técnicos do debate, em relação à infraestrutura da Internet. 
Após compreender aspectos relevantes de cada um dos atores, instituições e participantes de forma geral e separada por audiência, passa-se à análise comparativa destes em momento anterior e posterior ao Marco Civil da Internet, com o Gráfico abaixo (Figura 7).

\section{Figura 7}

Gráfico Atores em momento anterior e posterior ao $\mathrm{MCl}$

\section{PRÉ MCI}

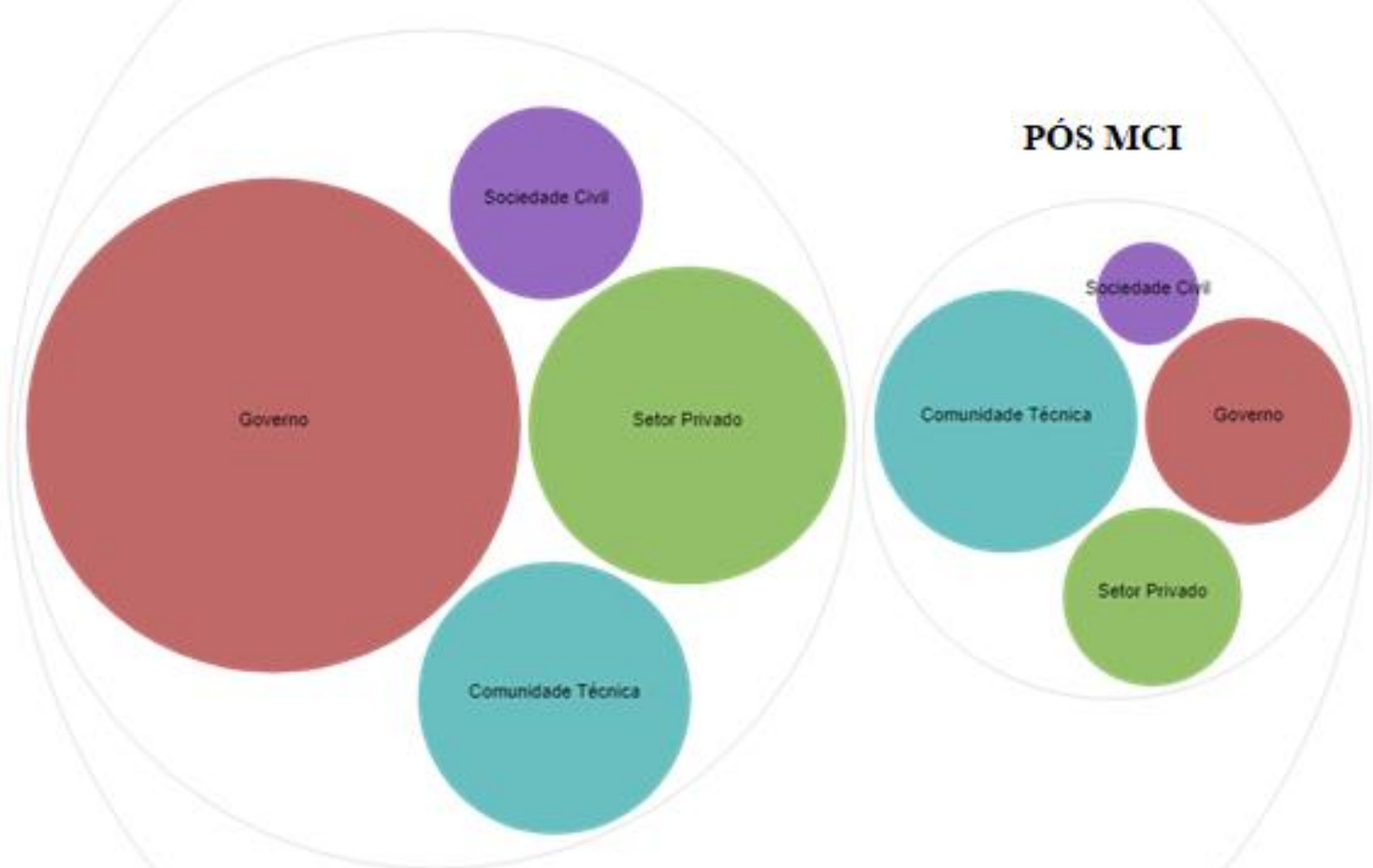

Fonte: Produzido pelos autores 
Os atores mais representados nas audiências anteriores ao $\mathrm{MCl}$ são o Governo e o Setor Privado, seguido da Comunidade Técnica e Sociedade Civil. Enquanto no momento posterior ao $\mathrm{MCl}$ a Comunidade Técnica é a que aparece representada, seguida do Governo, Setor Privado e Sociedade Civil.

Outro elemento relevante para análise da instituição que possui maior participação de acordo com o Gráfico acima, qual seja a Câmara dos Deputados, é perceber quais partidos os Deputados participantes representavam à época das audiências e a proporção de participação. Cabe destacar, ainda, que nesse segundo momento de audiência posterior ao $\mathrm{MCl}$, representantes da Câmara dos Deputados não foram ouvidos. Isso coloca uma questão para regulação: é o convencimento técnico que impera nas decisões do STF ou também os julgadores buscam remontar o quadro político da tomada de decisão? Nesse caso, uma coisa a se destacar é como em sede de controle de constitucionalidade os debates legislativos são recepcionados.

\section{Figura 8}

Distribuição de Deputados por audiência classificada por partido 


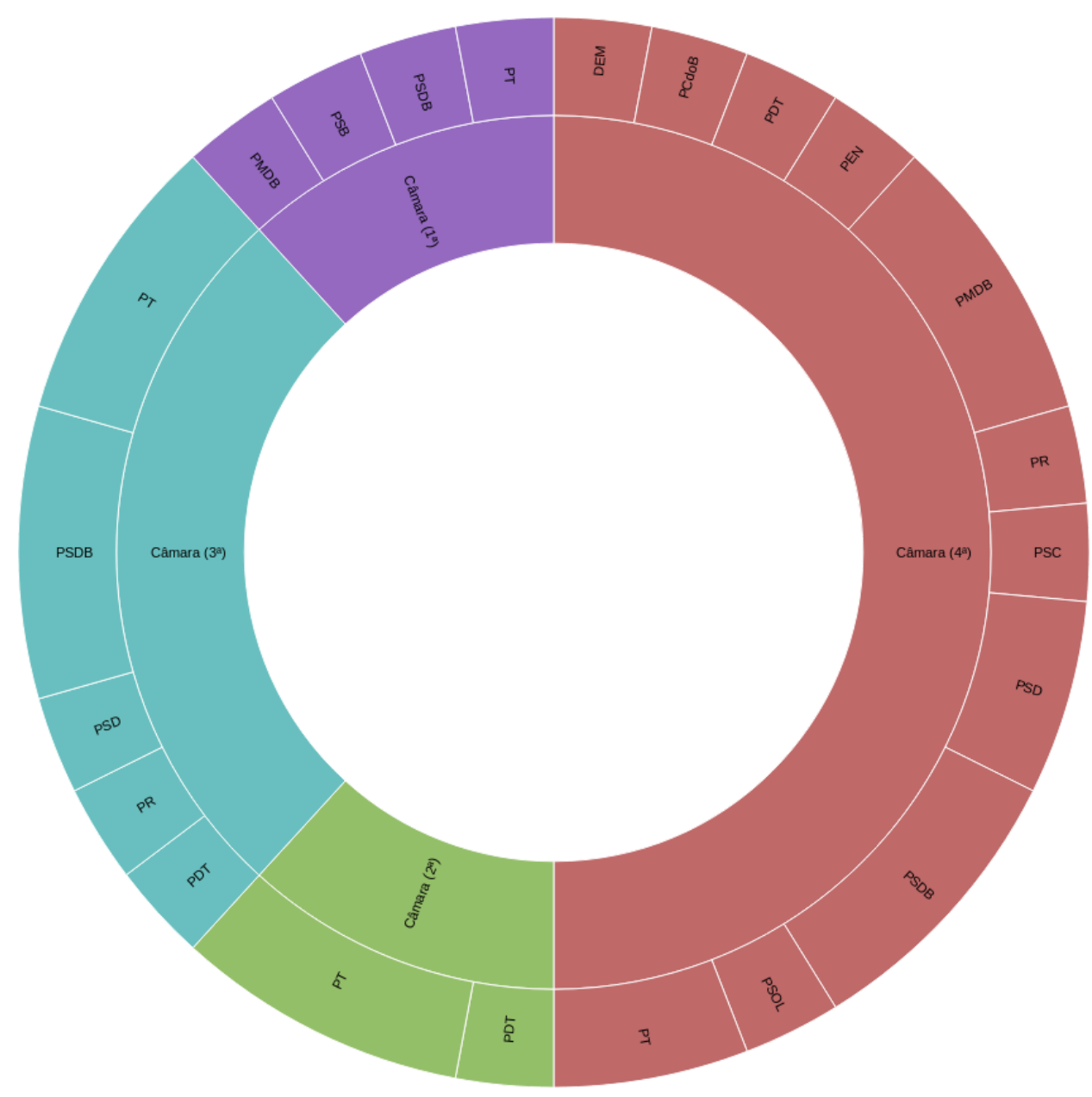

Fonte: Produzido pelos autores

O Gráfico acima (Figura 8) demonstra que a $4^{\mathrm{a}}$ audiência da Câmara dos Deputados possuiu a maior quantidade de Deputados no número de 16. Além disso o Partido dos Trabalhadores (PT) é o único que está representado em todas as 4 audiências, partido que o Relator, Deputado Alessandro Molon, do Projeto de Lei do $\mathrm{MCl}$ fazia parte. Outra análise que se pode extrair é que o PMDB e o PSBD, partidos de oposição à época, não tinham tanta participação nas primeiras audiências, sendo que na $4^{\mathrm{a}}$ eles são maioria, o que se pode justificar pelo fato de - Deputado Eduardo Cunha, líder do PMDB à época ter convocado a audiência.

Se depreende essa evolução na participação dos partidos ao longo das audiências. Ratifica-se a informação que na última audiência haviam mais deputados quantitativamente, mas esse aumento também se repercute no aumento de legendas dos partidos interessados que participaram. Até a terceira 
audiência apenas 5 partidos estavam representados, aumentando para 12. É possível se concluir que houve crescimento do interesse de legendas diferentes pelo tema ao longo do processo do $\mathrm{MCl}$.

Um outro elemento que merece destaque é a distribuição de participantes por Gênero, já que é possível compreender que a presença da diversidade de gênero no debate da regulação da Internet poderia contribuir para um outro modelo de regulação. A discussão sobre a regulação inicia-se no Brasil, como explorado na seção 4 deste trabalho, com a Lei da Carolina Dieckman e o caso Daniela Cicarelli de remoção de conteúdo. Ambos são casos que envolvem a exposição da mulher no ambiente virtual. Uma leitura mais sensibilizada para causas femininas e para questões de gênero poderia, por exemplo, levar a opções regulatórias diferentes das que foram feitas com legislações que optem pela linha do punitivismo, como o PL Azeredo.

Os dois gráficos a seguir mostram essa classificação dentro do universo total de atores e na divisão por audiência.

\section{Figura 9}

Distribuição de Gênero dos participantes

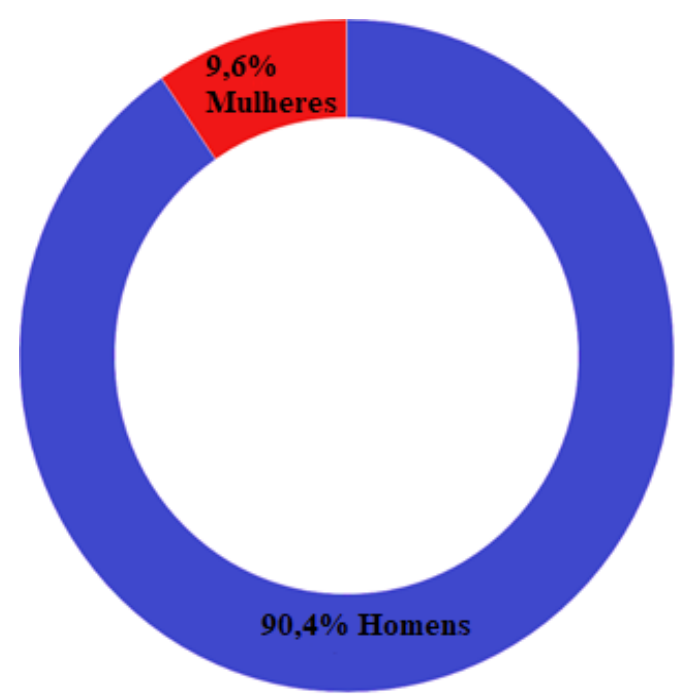

Fonte: Produzido pelos autores 
Dos 115 participantes das 5 audiências, apenas 11 eram mulheres (9,6\%), sendo 104 homens $(90,4 \%)$, como pode-se notar do Gráfico acima (Figura 9). Sendo que do universo de 11 mulheres, 3 delas participaram da audiência posterior ao Marco Civil da Internet e 8 das 4 audiências anteriores ao Marco Civil. Na primeira e na segunda apenas uma mulher em cada participou, na terceira participaram duas mulheres e na quarta as outras quatro.

\section{Figura 10}

Distribuição de Gênero por Ator

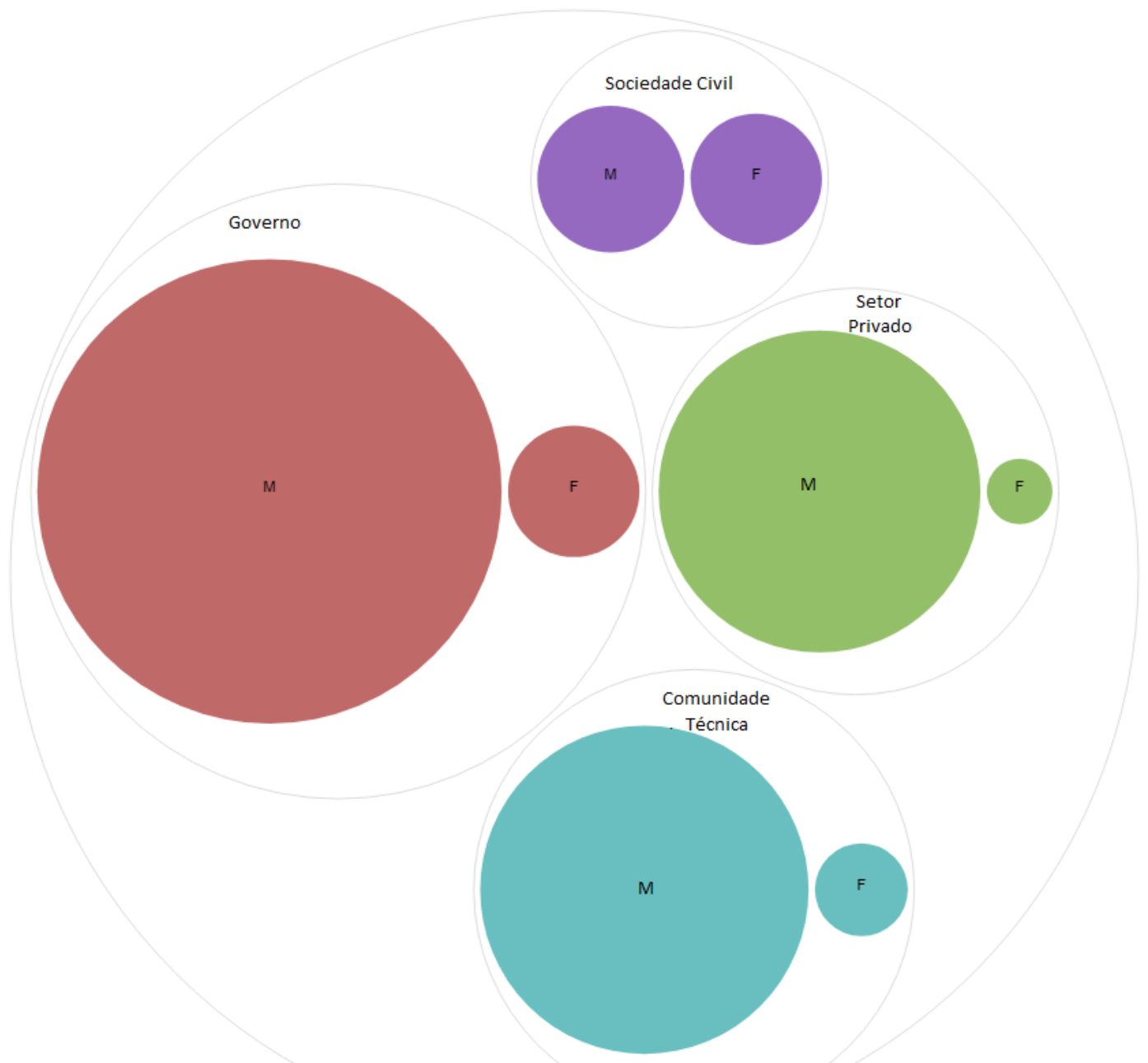

Fonte: Produzido pelos autores 
Percebe-se, também, a partir do Gráfico (Figura 10), que a proporção entre homens e mulheres se mantém apenas em representantes do ator sociedade civil em que os círculos são equivalentes, sendo dos 9 atores no total, 5 homens e 4 mulheres. Enquanto isso, nos demais atores a quantidade de homens é muito maior, sendo 4 no Governo (2 deputadas e 2 do MPF), 2 da Comunidade Técnica e uma do Setor Privado. Os dados que dizem respeito ao gênero dos participantes das audiências revelam a perpetuação da voz da presença masculina nesses espaços de Governança na Internet de forma quase unânime, cujo movimento \#MulheresnaGovernança vem tentando combater.

A discussão de gênero coloca-se com a predominância masculina e o debate perpassa a questão da representatividade e da ausência de diversidade nos ambientes de participação. Advém daí efeito imediato acerca da criação de políticas públicas que não levem em consideração questões de gênero, como pautas femininas de regulação do tema de "revenge porn", sem a culpabilização da vítima, por exemplo. Além disso, a inclusão de dados de apps de ciclo menstrual, como dados sensíveis, os quais inicialmente não seriam reconhecidos na discussão se não fosse a presença de mulheres no debate para demonstrar como são dados que dizem respeito à sexualidade e ao gênero. Então, nota-se a ausência de mulheres na construção do ambiente regulatório da Internet e a necessidade de se tratar do tema mesmo que de forma tangencial, não sendo o objeto central deste trabalho, a fim de abrir campo para novas pesquisas aprofundarem a discussão no ambiente acadêmico.

A partir dos dados apresentados nesta seção, pode-se extrair as seguintes considerações finais e resultados:

No momento anterior ao $\mathrm{MCl}$, o Governo, como autor do pré-projeto do Marco Civil é um dos principais interessados em defender sua aprovação e que a regulação da Internet no Brasil seja principiológica e não tenha um caráter punitivista como as discussões até então do PL Azeredo. A representação desse ator também é bastante expressiva pela quantidade de Deputados que participaram, tendo em vista que as 4 audiências ocorreram no Congresso. Já o Setor Privado foi o ator principal interessado, nesse momento, em que alguns 
temas como a neutralidade de rede não fossem regulados. Apesar de divergências dentro dos representantes do "ator" (setor empresarial), parte dele era contrário à aprovação de uma norma regulando a Internet, já que o segmento das Telecomunicações acreditava que as normas de Telecom já seriam suficientes e que uma norma principiológica e aberta daria margem a interpretações equivocadas.

Já no momento posterior ao $\mathrm{MCl}$, por se tratar de uma audiência pública no bojo de uma ação do controle de constitucionalidade que põe em jogo elementos de segurança da rede e a quebra da privacidade, como a criptografia, muitos grupos de estudos, ligados a diversas universidades do país e institutos que pesquisam o tema se inscreveram para apresentar elementos técnicos e políticos contrários, motivo pelo qual a Comunidade Técnica é o ator mais representado nesse momento. O Governo aparece como segundo ator mais atuante diante do contraponto que alguns órgãos ligados ao aparelho investigativo do Estado, como o MPF e a PF, apresentam para a flexibilização dessa segurança forte defendida pela Comunidade Técnica. Como principais interessados em regular o tema para fortalecer sua atuação nos combates à atuação criminosa, o Governo apresenta o contraponto dos argumentos utilizados pelos pesquisadores, a fim de possibilitar instalação de backdoors e semelhantes, bem como permitir a quebra ou proibição da criptografia quando necessário para alguma apuração e investigação.

No que diz respeito às instituições com maior incidência nos espaços de participação anteriores ao MCl, tem-se a Câmara dos Deputados, a SAL/MJ, o IDEC, a Abranet e a presença de advogados autônomos que foram convidados por parlamentares. Enquanto no espaço de debate posterior ao $\mathrm{MCl}$, a PF, o MPF e a USP são os atores com maior participação. Destaca-se que se optou por uniformizar os grupos de pesquisa da USP, que apesar de possuírem expertises distintas, em sua maioria representavam institutos de pesquisa de matemática ou engenharia com interesse na preservação da criptografia e em elementos que garantam segurança no uso das aplicações da Internet.

Como resultados, percebe-se o Governo teve maior protagonismo em todas as audiências ocorridas na Câmara dos Deputados, enquanto a Comunidade 
Técnica apresentou maior participação na audiência do STF, no momento posterior ao Marco Civil da Internet. A Sociedade Civil ou Terceiro Setor é o ator que menos apareceu nos debates, o que não diminui a força e a importância que esse ator possui no processo legislativo no tema. Nota-se que com a formação da Coalizão de Direitos na Rede, em 2016, possibilitando a organização dessas entidades, houve aumento do protagonismo de instituições no processo de advocacy no Congresso Nacional, com atuação relevante em temas de Internet.

Dito isso, em termos de dados, na primeira audiência, predominou a presença de representantes do Governo, em um total de 12 participantes, 8 eram do Governo $(66,66 \%)$, enquanto Setor Privado e a Comunidade Técnica estavam com 2 representantes cada (16,67\%). Não houve representantes do Terceiro Setor. Já, na segunda, no total de 11 participantes, o Governo possui pouco mais da metade, com 6 participantes (54,54\%), o Setor Privado em segundo lugar com 3 participantes $(18,18 \%)$ e, em seguida, a Sociedade Civil e Comunidade Técnica com 1 representante cada $(9,09 \%)$.

A terceira audiência anterior ao Marco Civil da Internet contou com 10 representantes do Governo (58,82\%), 4 do Setor Privado (23,52\%), 2 da Sociedade Civil (11,77\%) e em último lugar a Comunidade Técnica com 1 representante (5,88\%) em um universo de 17 participantes. A quarta, e última, audiência na Câmara possuiu 46 participantes, grande parte deles parlamentares, sendo 22 do Governo (47,82\%), 12 do Setor Privado (26,08\%), 8 da Comunidade Técnica (17,39\%) e por último a Sociedade Civil com 4 representantes (8,69\%).

No STF, a Comunidade Técnica possuiu a maior quantidade de representantes, diante da necessidade de ouvir e discutir sobre elementos técnicos do tema, o que pesquisadores e estudiosos sobre o tema desde a área da infraestrutura, até elementos regulatórios, poderiam contribuir melhor, em um total de 29 participantes, 13 representavam esse setor (44,82\%), 8 representavam o Governo (27,58\%), 6 o Setor Privado (20,68\%) e a Sociedade Civil em minoria apenas com 2 representantes (6,89\%). No total das seções, 115 participantes, sendo 54 $(46,95 \%)$ representantes do Governo, o que envolve parlamentares nas primeiras 4 
audiências, 27 da Comunidade Técnica (23,47\%), 25 do Setor Privado (21,73\%) e 9 da Sociedade Civil (7,82\%).

A ADI 5527 e a ADPF 403 que são o pano de fundo para a quinta audiência pública analisada voltaram à pauta do STF no final de maio de 2020 e encontra-se em vista do Ministro Alexandre de Moraes. O julgamento foi iniciado e o Ministro Edson Fachin, Relator da ADPF, que acompanhou a Ministra Rosa Weber, Relatora da ADI, proferiram seus votos no sentido de declarar inconstitucionalidade parcial sem redução de texto do inciso II do art. $7^{\circ}$ e do inciso III do art. 12 do $\mathrm{MCl}$, isto é, a quebra do sigilo de comunicação em aplicativos de mensagens é inconstitucional. A questão por trás dessas ações de controle são a possibilidade de suspensão dos serviços de mensagens pela internet, como o aplicativo WhatsApp, pelo suposto descumprimento de ordens judiciais que determinem a quebra de sigilo das comunicações. O Min. Edson Fachin inclusive afirmou que os direitos digitais são direitos fundamentais. Os argumentos da Comunidade Técnica e da Sociedade Civil apresentados na audiência pública do STF analisada parecem estar refletidos nos primeiros votos dessa decisão ainda em desenvolvimento. Além disso, esse argumento do Judiciário reafirma o debate contemporâneo do legislativo da Proposta de Emenda à Constituição - PEC 17/2019, que tem como objetivo considerar a proteção de dados como direito fundamental.

\section{CONCLUSÃO}

Assim, conclui-se que a hipótese apresentada de que o Governo e a Sociedade Civil seriam os maiores participantes da discussão anterior ao $\mathrm{MCl}$ é afastada em parte. Apesar de o Governo ser o principal ator nesse espaço, a Sociedade Civil apresenta menor expressividade e, portanto, o Setor Privado releva maior participação nesse momento. Enquanto a hipótese que, no momento posterior ao $\mathrm{MCl}$, a Comunidade Técnica ganha protagonismo se ratifica. Isso decorre da necessidade de se ouvir sobre elementos de infraestrutura da Internet e da preocupação dos grupos de pesquisa de diversas áreas sobre a discussão da proteção à privacidade e manutenção de uma criptografia forte. Embora as 
audiências públicas sejam consideradas espaços de participação social, verificouse que os atores externos ao Estado tiveram envolvimento muito menor do que os agentes oficiais dos três Poderes.

Essa conclusão se relaciona com a construção da regulação da Internet no Brasil, ao demonstrar a janela de oportunidade criada e utilizada pelo Governo à época da votação do $\mathrm{MCl}$, pelo fato de ser o principal ator interessado nos ambientes de participação, analisados nesta pesquisa, desse processo regulatório. Além de demonstrar que o Setor Privado é outro grupo de interesse preocupado com as repercussões do $\mathrm{MCl}$ para a economia digital e para o setor de telecomunicações.

Por sua vez, no momento posterior ao $\mathrm{MCl}$, a presença da Comunidade Técnica revela o aparecimento de inúmeros estudos, institutos e órgãos interessados em temas ligados à regulação da Internet e aos seus elementos técnicos, motivados pelo ambiente já principiologicamente regulado, a partir do $\mathrm{MCl}$. Esses estudos, que vem sendo desenvolvidos desde então, têm por interesse entender a aplicabilidade do $\mathrm{MCl}$ e discutir seus efeitos, o que justifica a presença da Comunidade Técnica em sua maioria no ambiente participativo 3 anos após o $\mathrm{MCl}$. Em relação a isso, a análise aponta para um modelo regulatório como o proposto por Murray (2007), em que há uma interação entre os atores e um comunitarismo em rede, demonstra o papel da formação e consolidação da política pública deste tema, inclusive com sua fase de avaliação.

Este trabalho complementa o trabalho de Solagna (2015) e tantos outros estudos melhor explorados na seção 4, pelo fato de aquele "explica o encadeamento dos acontecimentos, o papel dos atores-chave envolvidos, os setores em disputa, e, por fim, as janelas de oportunidades que tornaram possível o nascimento e aprovação do Marco Civil da Internet" sem abordar aspectos jurídicos e institucionais da chamada "constituição da Internet". O MCl, então, é visto como um instrumento regulatório, como no trabalho de Solagna (2015), e nesse estudo os elementos investigados alinham-se a visão adotada neste trabalho, percebendo o marco como um dos elementos que compõe a construção e sedimentação da regulação da Internet no Brasil. 
Assim, pode-se perceber das análises realizadas que o Judiciário não reproduz o debate do Legislativo, mas reafirma a importância da regulação do tema para a tomada de decisões. Mesmo privilegiando um aspecto técnico de segurança e privacidade nos discursos utilizados, mantém-se a concepção de o Marco Civil da Internet é um instrumento regulatório importante e que deve ser levado em consideração na tomada de decisões, inclusive transformando os direitos incorporados por esse marco regulatório em dispositivos constitucionais.

\section{REFERÊNCIAS}

Barlow (1996). Declaration of the Independence of Cyberspace. Disponivel em: https://www.eff.org/cyberspace-independence. Acesso em: 09 abr. 2020.

Bauer, J. (2007) Internet Governance: Theory and First Principles. In: ANDAMUTHA, R. K. J. (ed.). Internet Governance: an Introduction. Hyderabad: Icfai University Press, 40-59.

Bragatto, R. C.; Sampaio, R. C.; Nicolás, m. A. (2015) A segunda fase da consulta do Marco Civil da Internet: como foi construída, quem participou e quais os impactos? Eptic (UFS), v. 17, 236-255.

Calmon, P.C. Du P.; da costa, M.M. Análise de Políticas Públicas no Brasil: estudos sobre a formação da agenda governamental. XXXI ANPAD. Rio de Janeiro, 2007.

Cruz, F. C. B. (2015) Direito, Democracia e cultura digital: a experiência de elaboração legislativa do Marco Civil da Internet. (Mestrado em Direito) Universidade de São Paulo, 138 f.

Denardis, L. (2013) The emerging field of Internet governance. In.: DUTTON, W. The Oxford handbook of Internet Studies. Oxford: Oxford University Press, 555575.

Lessig, L. (2006) Code and the others laws of cyberspace, version 2.0. Basic Books.

Mancuso, W. P (2004). O lobby da indústria no Congresso Nacional: empresariado e política no Brasil contemporâneo. Dados [online]. vol.47, n.3, pp.505-547. ISSN 1678-4588. https://doi.org/10.1590/S0011-52582004000300003.

Murray, A. (2011) Nodes and gravity in virtual space. Legisprudence, 5 (2)., 195-221.

Murray, A. (2007) The regulation of cyberspace: control in the online environment. New York: Routledge-Cavendish. 
Musiani, F.; Cognurn, D.; Denardis, L; Levinson, N. (ed.) (2016) The turn to infrastructure in Internet governance. London: Palgrave-Macmillan.

Nolasco, J. (2014) Acessando a rede: um olhar sobre a formação da agenda para regulação da internet no Brasil. Dissertação de Mestrado. Fundação Getúlio Vargas.

Posner, R (1975). The Social Cost of Monopoly and Regulation. Journal of Political Economy, Vol.83, p. 807-27.

Reidenberg, J (1996), Governing Networks and Rule-Making in Cyberspace, 45 Emory Law Journal 911.

Rená, P (2010). O Direito Achado na Rede: A Emergência do Acesso à Internet como Direito Fundamental no Brasil. [Dissertação]. Mestrado em Direito, Estado e Constituição. Universidade de Brasília.

Soares, P. F (2016). A regulação diante da evolução da essencialidade do serviço público: a reclassificação da banda larga como serviço de telecomunicações nos Estados Unidos. Dissertação (Mestrado em Direito) - Universidade de Brasília, Brasília, 202 f.

Solagna, F (2015). A formulação da agenda e o ativismo em torno do Marco Civil da Internet. Dissertação (Mestrado em Sociologia) - Universidade Federal do Rio Grande do Sul.

Sustein, C. R (2001). Republic.com. Princeton: Princeton University Press.

Vermeule, A. (2016) Law's Abnegation: From Law's Empire to the Administrative State. Cambridge, Massachusetts: Harvard University Press.

Vianna, M (1994). Lobismo: Um Novo Conceito para Analisar a Articulação de Interesses no Brasil, Centro de Estudos de Políticas Públicas, Texto para Discussão Nº. 25, Rio de Janeiro.

'Amanda Nunes Lopes Espiñeira Lemos: Mestre em Direito pela Universidade de Brasília. Membro do Grupo de Pesquisa Observatório de Políticas Públicas (GEOPP). Pesquisadora do Laboratório de Políticas Públicas e Internet (LAPIN), ORCID.

iAna Cláudia Farranha: Doutora em Ciências Sociais (UNICAMP). Professora da Faculdade de Direito e do Programa de Pós-Graduação em Direito da Universidade 
de Brasília. Coordenadora do Grupo de Pesquisa Observatório de Políticas Públicas (GEOPP). ORCID.

iiilsaac Reis: Doutor e mestre em Direito. Professor da Faculdade de Direito da Universidade de Brasília. Co-líder do Grupo de Pesquisa Retórica, Argumentação e Juridicidades (GPRAJ), $\underline{\text { ORCID. }}$

Data de submissão: 04/01/2021.

Data de aprovação: 05/04/2021. 